\title{
KELEMBAGAAN MASYARAKAT DALAM PENGEMBANGAN PROGRAM PERHUTANAN SOSIAL: STUDI KASUS KABUPATEN MANOKWARI
}

\section{(Community Institution in Developing Social Forestry Program: Study Case in Manokwari District)}

\author{
Fiktor Theodorus Horota ${ }^{1}$ Bambang Nugroho ${ }^{1}$ dan Jonni Marwa ${ }^{1 凶}$ \\ Jurusan Kehutanan, Fakultas Kehutanan Universitas Papua Manokwari, Papua Barat, \\ 98314. Tlp/Fax: +62986211065 . \\ ${ }^{\square}$ Penulis Korespondensi: Email: jonnimarwa@gmail.com \\ Diterima: 10 Sep 2018| Disetujui: 12 Oct 2018
}

\begin{abstract}
Abstrak
Penelitian ini bertujuan untuk menilai peran dan fungsi kelembagaan masyarakat yang terlibat dalam program-program PS yang sudah dan atau sedang dijalankan di Kabupaten Manokwari. Pendekatan metode yang digunakan yakni metode studi kasus, yang mana sebagai kasus dalam penelitian ini adalah peran dan fungsi anggota kelompok dalam pengembangan program PS. Responden yang diwawancarai dalam penelitian ini terdiri dari responden kunci adalah setiap ketua kelompok dalam lembaga dan pendamping kegiatan dari instansi terkait. Hasil penelitian menunjukkan bahwa terdapat tiga kelompok kebun rakyat di tiga lokasi yang berbeda yaitu: kelompok Ofoncu Efeina (Kelurahan Amban), Udopi (Kampung Masepi) dan Sarina (Kampung Sarina). Penggunaan areal untuk membangun areal pembibitan dilakukan pada hak milik anggota kelompok. Keterlibatan stakeholder sangat berperan dalam mendukung realisasi kegiatan PS yang cukup efektif. Hasil evaluasi kelembagaan masyarakat yang melaksanakan program PS pembuatan kebun bibit rakyat di Kabupaten Manokwari dinilai sangat lemah dan mengahadapi tantangan besar namun disisi lain peluang dari luar sangat besar jika kelembagaan masyarakat dapat ditata dan dikembangkan.
\end{abstract}

Kata kunci: Kelembagaan masyarakat, perhutanan sosial, kebun bibir rakyat, analisis SWOT

\begin{abstract}
To assess role and function of community institution that engaged in numerous social forestry programs in Manokwari district, this study is carried out. Methodology approach that applied is a case study in which the case is role and function of group members in the social forestry program development. Selected respondents, either key or common, were interviewed through a number of questions in regard to the program as well related stakeholders that have been actively involved. The result pointed out three groups that has been stablished in three different locations such as: Ofoncu Efeina (located in Amban), Udopi (located in Masepi village) dan Sarina (located in Sarina village). Lands for the seedling plants have been available and obtained from the grouped member by given. Stakeholders engagement were pivotal in driving the realization of the social forestry program such as issuing regulations and policies. It turned out that evaluation in community institution that carried out the social forestry program for seedling garden
\end{abstract}


establishment in Manokwari was so weak and had a difficult challenge in the future. However, it had several opportunities from outside if the community institutions being remanaged and developed well.

Keywords: Community institution, social forestry, people seedling garden, SWOT analysis

\section{PENDAHULUAN}

Undang-Undang Nomor 41 tahun 1999 Tentang Kehutanan memberikan ruang kepada masyarakat untuk ikut mengelola kawasan hutan. Bentuk pengelolaan hutan oleh masyarakat adalah merupakan inti dari konsep perhutanan sosial (PS) yang sekarang ini menjadi paradigma baru dalam pembangunan sektor kehutanan. Pemerintah melalui Departemen Kehutanan mencanangkan program perhutanan sosial sebagai upaya perbaikan kondisi hutan di Indonesia sekaligus dapat meningkatkan kesejahterakan masyarakat di dalam dan di sekitar hutan (Elisabeth 2017). Inti dari program Perhutanan Sosial adalah masyarakat terlibat aktif secara langsung dalam pengelolaan hutan dengan tujuan masyarakat dapat sejahtera dan kondisi hutan bisa lebih baik.

Berdasarkan paradigma PS tersebut maka keberhasilan pembangunan kehutanan sangat ditentukan oleh sejauh mana tingkat partisipasi masyarakat dalam berkontribusi terhadap upaya pengelolaan hutan dan kualitas sumberdaya manusia yang mendukungnya (Firdaus 2018). Dalam upaya pengembangan kualitas masyarakat khususnya yang bermukim di dalam dan sekitar hutan agar maju dan mandiri sebagai pelaku pembangunan kehutanan, maka strategi pemberdayaan masyarakat dalam upaya rehabilitasi hutan dan lahan mutlak dilaksanakan. Aspek kelembagaan mempunyai peranan sangat besar bagi kesuksesan pembangunan hingga dapat dikatakan bahwa kegagalan pembangunan umumnya dikarenakan lemahnya kelembagaan yang ada termasuk sektor di kehutanan (Kartodihardjo 2006).

Dalam rangka mewujudkan masyarakat yang mandiri sebagai pelaku pembangunan kehutanan dimasa yang akan datang sebagaimana semangat dalam PS, maka hal yang sangat urgen dilakukan adalah membangun, memperkuat dan mengembangkan kelembagaan masyarakat yang terkait dengan pembangunan kehutanan (Kartodihardjo 2006).

Rehabilitasi hutan dan lahan saat ini telah diarahkan sebagai gerakan berskala nasional yang terencana, terpadu dengan melibatkan berbagai pihak terkait, baik pemerintah, swasta dan masyarakat luas melalui suatu perencanaan, pelaksanaan serta pemantauan dan evaluasi yang efektif dan efisien. Pemerintah melalui program peningkatan fungsi dan daya dukung daerah aliran sungai (DAS) berbasis pemberdayaan masyarakat telah melaksanakan kegiatan yang ditujukan untuk meningkatkan kesejahteraan masyarakat pedesaan diantaranya melalui pembuatan kebun bibit rakyat (KBR), pengembangan hutan kemasyarakatan (PHK) dan hutan desa (HD), maupun pengembangan hutan rakyat (PHR) (Puspitojati dkk. 2014; Aji dkk. 2015).

BPDAS Remu-Ransiki melalui Dinas Kehutanan Kabupaten Menokwari telah melaksanakan Program rehabilitasi hutan dan lahan melalui pembuatan kebun bibit 
rakyat diaksanakan secara swakelola oleh kelompok masyarakat. Kabupaten Manokwari mendapat alokasi anggaran guna pembuatan KBR yang dikelola secara swakelola. Bibit hasil dari kebun bibit rakyat yang dibuat secara swakelola ini digunakan untuk tujuan atau penanaman hutan rakyat, merehabilitasi hutan dan lahan kritis serta kegiatan penghijauan lingkungan. Dengan demikian, penelitian ini bertujuan untuk menilai peran dan fungsi kelembagaan masyarakat yang terlibat dalam programprogram PS yang sudah dan atau sedang dijalankan di Kabupaten Manokwari. Sehingga melalui kegiatan ini, diharapkan dapat memberikan informasi dasar kepada pemerintah pusat maupun pemerintah daerah dalam pengembangan program PS dan pemberdayaan kelembagaan masyarakat berbasis kehutanan sehingga kelestarian hutan dapat terjaga.

\section{METODE PENELITIAN}

\section{Risalah Umum Penelitian}

Penelitian ini secara khusus difokuskan pada Distrik Manokwari Barat (Kelurahan Manokwari Timur dan Kelurahan Amban) dan Distrik Manokwari Selatan Kampung Udopi, yang berlangsung selama \pm 1 bulan yaitu dari bulan Juni s/d Juli tahun 2016. Yang menjadi obyek dalam penelitian ini yaitu basis lokasi pelaksanaan program PS di Kabupaten Manokwari. Sementara subyek penelitian adalah anggota masyarakat yang tergabung dalam kelompok kelembagaan yang melaksanakan program PS.

\section{Metode Penelitian}

Pendekatan metode yang digunakan yakni metode studi kasus, yang mana sebagai kasus dalam penelitian ini adalah peran dan fungsi anggota kelompok dalam pengembangan program PS di Kabupaten Manokwari. Dengan demikian, metode yang digunakan dalam penelitian ini adalah metode deskriptif dengan teknik studi kasus dan wawancara semi struktural. Sedangkan data yang dikumpul adalah data kuantitatif dan kualitatif.

\section{Variabel Pengamatan}

Variabel yang diamati dalam penelitian ini adalah: Faktor eksogen yang meliputi kondisi fisik/material. Letak lokasi kegiatan KBR, kondisi dan status lokasi penanaman. Selian itu atribut komunitas di dalam kelompok masyarakat pengelola program PS di Kabupaten Manokwari. Aturan main formal: yang dilaksanakan dalam kelompok masyarakat pengelola program perhutanan sosial di Kabupaten Manokwari dan norma-norma/aturan adat yang dijalankan dalam kelembagaan masyarakat pengelola program PS di Kabupaten Manokwari.

Sementara aktor-aktor dalam arena aksi meliputi: pemerintah yang memainkan peran dalam program pelaksanaan PS di Kabupaten Manokwari (BPDAS-Remu Ransiki, Dinas Kehutanan Kabupaten Manokwari, Pemerintah Kabupaten Manokwari, LSM). Selain itu masyarakat yang terlibat dalam pelaksanaan program KBR/PS (penanaman hutan rakyat). 


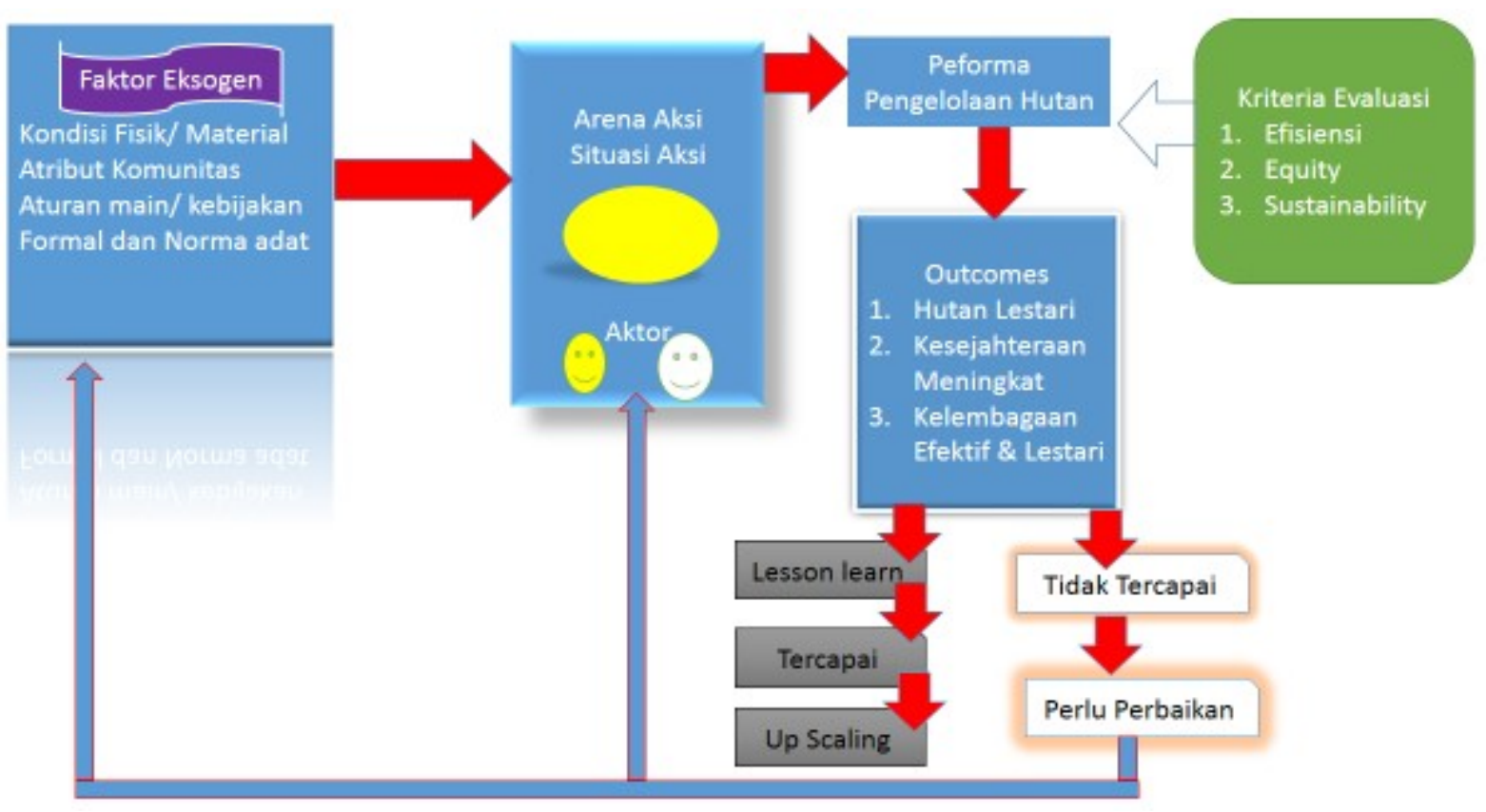

Gambar 1. Teknik analisis kelembagaan (Ostrom 2008).

\section{Pelaksanaan Penelitian}

\section{Teknik Penentuan Responden}

Responden yang diwawancarai dalam penelitian ini terdiri dari responden kunci adalah setiap ketua kelompok dalam lembaga dan pendamping kegiatan dari instansi terkait. Responden umum yaitu anggota masyarakat yang terlibat dalam kelompok pengelola program perhutanan sosial ini.

\section{Pengumpulan data}

Data yang dikumpulkan dalam penelitian ini meliputi data primer dan data sekunder. Data Primer diperoleh dari hasil wawancara dan observasi lapangan, Sedangkan data sekunder diperoleh BPDAS Remu-Ransiki dan Dinas Kehutanan Kabupaten Manokwari serta melalui literatur dengan cara pencarian di internet, studi pustaka dan laporan hasil penelitian yang berkaitan dengan penelitian ini.

\section{Pengolahan Data}

Menggunakan teknik analisis kelembagaan (instituion analysis development/IAD) (Ostrom 2008). IAD adalah kerangka analisis pengembangan kelembagaan/institusi yang menyatakan peforma pengelolaanm hutan ditentukan oleh arena aksi (situasi aksi dan aktor), sedangkan situasi aksi dipengaruhi oleh faktor eksogen yang terdiri dari aspek fisik dan material, atribut komunitas, dan aturan main yang digunakan dalam pengelolaan hutan. Untuk menilai kekuatan, kelemahan, peluang dan ancaman dalam pengembangan program perhutanan sosial dilakukan analisis dengan pendekatan SWOT. Analisis 
SWOT adalah analisis kondisi internal maupun eksternal suatu organisasi yang selanjutnya akan digunakan sebagai dasar untuk merancang strategi dan program kerja. Analisis internal meliputi peniaian terhadap faktor kekuatan (strength) dan kelemahan (weakness). Sementara, analisis eksternal mencakup faktor peluang (opportunity) dan tantangan (threath).

\section{Analisa Data}

Data yang dilkumpulkan berupa data kulitatif dan kuantitatif selanjutnya dikuantitatifkan dan dianalisis secara deskriptif kemudian disajikan kedalam tabel dan gambar.

\section{HASIL DAN PEMBAHASAN}

\section{Kondisi Fisik Kebun Bibit Rakyat}

Kebun bibit rakyat Ofoncu Efeina terletak pada kordinat geografis LS : $0^{\circ}$ 50' 43.60' $\quad$ BT : $134^{\circ} 04^{\prime}$ 04.63" di kelurahan Amban Distrik Manokwari Barat berada pada lahan/lokasi milik masyarakat (hak ulayat) dengan luas persemaian $10 \mathrm{~m} \times 25 \mathrm{~m}(0,025 \mathrm{ha})$, topografi datar sampai berbukit. Luasan areal yang direncanakan guna penanaman seluas 100 ha terletak pada kordinat Lintang Selatan $0^{\circ}$ 50'40,48" dan Bujur Timur 134 $04^{\circ}$ '08,10". Jarak antara persemaian (KBR Ofoncu Efeina) dengan lokasi penanaman $\pm 150 \mathrm{~m}$. Jenis dan jumlah bibit/benih tanaman guna penanaman/pembuatan Hutan Rakyat ini adalah tanaman kehutanan dengan jenis Merbau (Intsia sp.) dengan jumlah 20.000 anakan dan Mahoni (Swietenia sp.) dengan 5000 anakan tanaman.

Kebun bibit rakyat Udopi berada di Distirk Manokwari Selatan Kampung Masepi, Kordinat geografis LS : $00^{\circ} 51^{\prime}$
86.04" dan BT : $134^{\circ} 00^{\prime} 96.08^{\prime \prime}$ dengan luasan kebun bibit/persemaian $10 \mathrm{~m} \times 25$ $\mathrm{m}(0,025 \mathrm{Ha})$ dengan topografi berbukit dan jarak dari lokasi KBR Udopi ke lokasi penanaman 10 meter dan luasan areal yang akan ditanami dengan bibit hasil KBR seluas 40 hektar. Pembuatan tanaman oleh kelompok kebun bibit rakyat Udopi ini dengan tujuan HR. Bibit yang dibuat oleh kelompok KBR Udopi adalah jenis Merbau (Intsia sp.) sebanyak 5000 bibit, Matoa (Pometia sp.) sebanyak 5000 bibit dan nyatoh (Palagium amboinensis) sebanyak 18.000 bibit/ benih.

Kelompok kebun bibit rakyat Sarina terletak pada kordinat geografis LS : $00^{\circ} 52^{\prime}$ 02,9' dan BT : $134^{\circ} 04^{\prime}$ 44,3 " lokasi persemaian berada \pm 45 $\mathrm{m}$ dpl. Luas lokasi persemaian $\pm 10 \mathrm{~m}$ $\times 25 \mathrm{~m}(0,025 \mathrm{ha})$. Berada di Distrik Manokwari Barat Kelurahan Manokwari Timur Kabupaten Manokwari. Jenis tanaman yang dibuat pada persemaian/kebun bibit rakyat ini adalah tanaman serba gunan (MPTS/multi-purpose tree spesies) dengan jumlah sebanyak 25.000 yaitu dari jenis nyatoh (Palagium amboinensis) 10.000 bibit/anakan dan pinang (Areca pinata) 15.000 bibit/anakan. Jarak antara persemaian dengan lokasi penanaman 20 meter.

\section{Atribut Komunitas Masyarakat}

Atribut komunitas dalam pelaksanaan program perhutanan sosial KBR ini adalah penggunaan lahan masyarakat adat sebagai lokasi pembuatan persemaian. Hal ini terjadi dalam kelompok Ofoncu Efeina dan kelompok Udopi yang melibatkan pemilik hak ulayat sebagai 
bagian dalam struktur keanggotaan kelompok pengelola program perhutanan social. Sedangkan atribut masyarakat adat yang merupakan bagian dari komunitas adat suku besar Arfak yang merupakan modal sosial tidak dilaksanakan dalam pengelolaan program perhutanan sosial ini.

Tabel 1. Kelompok Pengelola KBR Kabupaten Manokwari tahun 2015.

\begin{tabular}{|c|c|c|c|c|c|}
\hline No. & Nama Kel. & $\sum_{\text {Anggota }}^{\sum}$ & $\begin{array}{l}\text { Lokasi } \\
\text { Keg. }\end{array}$ & $\begin{array}{l}\text { Program } \\
\text { PS }\end{array}$ & $\begin{array}{l}\text { Bentuk } \\
\text { Keg. }\end{array}$ \\
\hline 1. & Sarina & 15 & $\begin{array}{c}\text { Kampung } \\
\text { Sarina }\end{array}$ & $\begin{array}{l}\text { Pembanguna } \\
\text { Hutan Rakyat }\end{array}$ & $\begin{array}{c}\text { Persemaian \& } \\
\text { Penanaman }\end{array}$ \\
\hline 2. & Udopi & 15 & $\begin{array}{c}\text { Kampung } \\
\text { Masepi }\end{array}$ & $\begin{array}{l}\text { Pembanguna } \\
\text { Hutan Rakyat }\end{array}$ & $\begin{array}{c}\text { Persemaian \& } \\
\text { Penanaman }\end{array}$ \\
\hline 3. & Ofoncu Efeina & 15 & $\begin{array}{c}\text { Kelurahan } \\
\text { Amban }\end{array}$ & $\begin{array}{l}\text { Pembanguna } \\
\text { Hutan Rakyat }\end{array}$ & $\begin{array}{c}\text { Persemaian \& } \\
\text { Penanaman }\end{array}$ \\
\hline
\end{tabular}

Atribut komunitas merupakan bagian dari bagian dari komunitas masyarakat adat Arfak yang mendiami wilayah di sekitar wilayah Masepi dan Amban. Penggunaan areal untuk membangun areal pembibitan dilakukan pada hak milik anggota kelompok sehingga tidak ada konsekuensi biaya. Hal ini juga berkaitan dengan lokasi penanaman yang didesain sedemikian rupa oleh ketua kelompok untuk dibangun di hak milik anggota dengan tujuan tidak ada ganti rugi, sebab ongkos ganti rugi tanah jauh lebih besar dari nilai proyek KBR yang hanya Rp. 50.000.000 secara bertahap. Dari analisis atribut komunitas dan aturan main yang digunakan masyarakat adat, tergambar suatu pola bahwa dalam pengelolaan KBR atau program perhutanan sosial maka kelembagaan yang dibangun harus memiliki prinsipprinsip:

1. Lembaga pengelola KBR (organisasi) harus menempatkan masyarakat pemilik hak ulayat sebagai ketua kelompok atau anggota dalam kelompok

2. Pengaturan pemanfaatan lahan untuk pembibitan ataupun penanaman berlandaskan pada tututan moral (etika) yang sesuai dengan kondisi adat masyarakat Arfak dan mengutamakan fungsi fisik (lingkungan), sosial dan ekonomi SDA tersebut bagi masyarakat sekitar

3. Pengaturan pengelolaan areal KBR bersifat spesifik lokasi.

4. Aturan main dibuat secara partsipatif, mengikutsertakan pihak-pihak terkait. Sebab dalam faktanya tidak ada aturan main berupa Anggara dasar dan anggaran rumah tangga kelompok atau kesepakatan berupa kontrak dan lain-lain. Semua aturan dibangun secara lisan, sehingga angggota kelompok bebas keluar masuk sesuai dengan kepentingan ekonomi dari pengelola KBR

5. Ada insentif ekonomi yang bersifat kentinyu dan terbagi secara merata

6. Apabila terjadi selisih antara anggota dalam kelompok maupun dengan pengelola dilakukan dengan perundingan.

Prinsip-prinsip ini sebagian besar tidak dipraktekan dalam implementasi program perhutanan di Kabupaten Manokwari. Karena lembaga yang dibangun tidak didesain untuk menciptakan efektifitas, keberlanjutan dan kesetaraan dalam pengelolaan program.

\section{Aturan Main/Kebijakan Formal}

Pelaksanaan program PS pembuatan bibit tanaman guna penaman hutan rakyat ini mengacu pada PERMENHUT No: 
P.12/ Menhut-II/ 2013 tentang Pedoman Penyelenggaran Kebun Bibit Rakyat dan PERMENHUT No: P.8/ Menhut-II/ 2013 tentang Pedoman Umum Pengembangan Perhutanan Masyarakat. Secara ringkas dapat dijelaskan bahwa pembentukan kelompok KBR terdiri dari 15 orang anggota kelompok dan terdapat lokasi penanaman KBR minimal 40 hektar. Selain itu, berada pada desa sasaran RHL berdasarkan Rencana Teknis RHL DAS atau RPRHL. Dalam suatu kampung dapat ditetapkan maksimal dua unit KBR. Dari sisi letak lokasi harus memenuhi syarat calon lokasi sesuai peraturan yang ditetapkan. Bibit yang dihasilkan digunakan untuk membangun hutan rakyat, penghijauan lingkungan dan lainlain. Kelompok harus mengajukan proposal pembangunan KBR yang disertai dengan keterangan kepala kampung/lurah atau distrik yang menyatakan bahwa kelompok tersebut benar-benar berada dalam lokasi yang bersangkutan. Setelah itu, Dinas Kehutanan Kabupaten Manokwari akan melakukan verifikasi dan kemudian ditetapkan atau ditolak. Bila KBR telah ditetapkan maka selanjutnya kelompok menyusun rencana usulan kegiatan kerja (RUKK). Skema penetapan KBR disajikan pada Gambar 2.

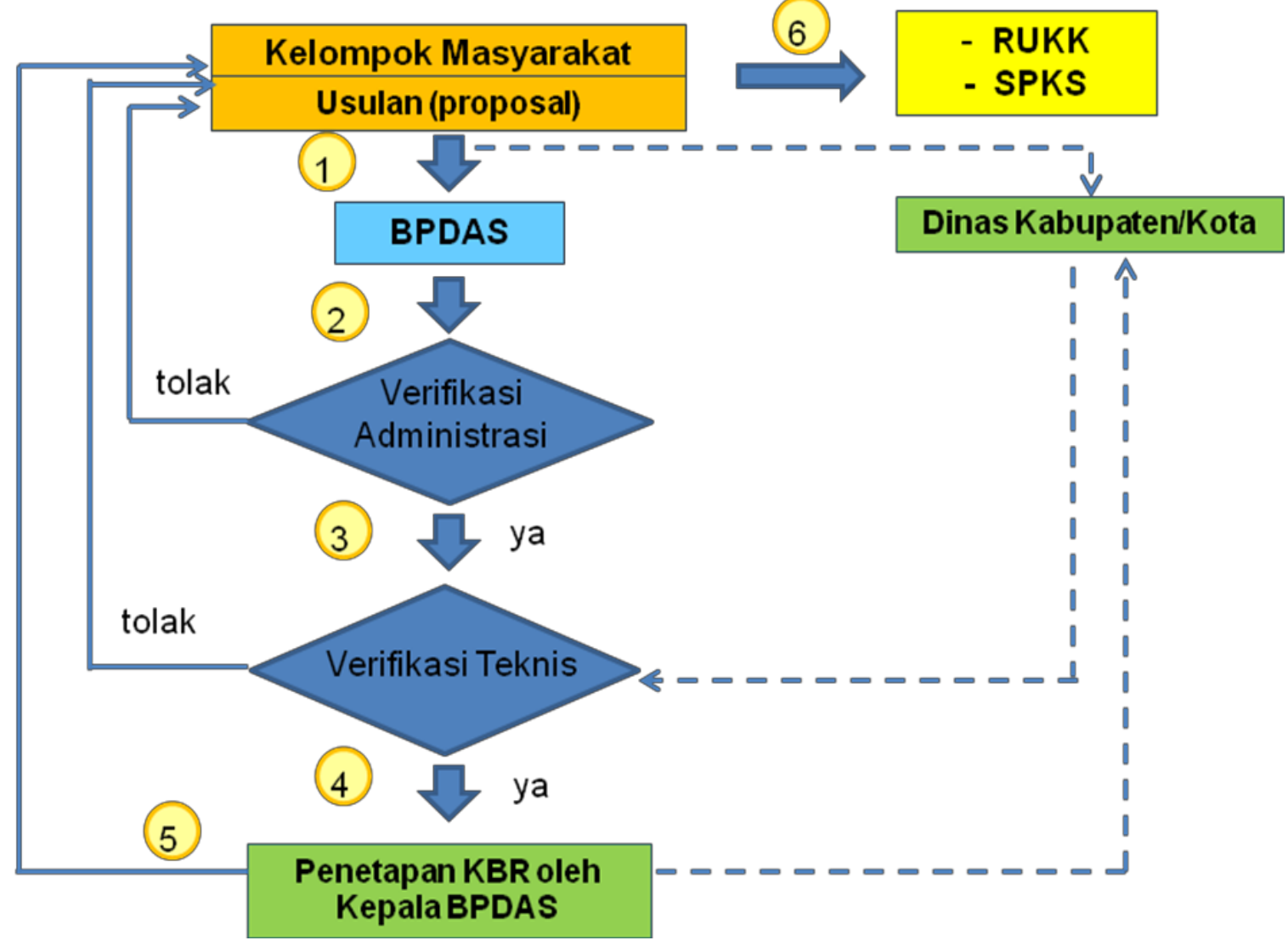

Gambar 2. Skema penetapan KBR 
Berdasarkan PERMENHUT No: P.8/Menhut-II/ 2013 tentang Pedoman Umum Pengembangan Perhutanan Masyarakat Pedesaan Berbasis Konservasi prosedurnya sama dengan KBR hanya berbeda pada penjabat pembuat komitmen dipegang oleh BPDAS. Sedangkan kuasa pengguna adalah Dirjen BP-DASPS (Balai Pemantuan Daerah Aliran Sungai dan Pehutanan Sosial). Jadi semua proses dikerjakan oleh BP-DAS sedangkan Dinas Kehutanan tidak terlibat sama sekali. Bagi masyarakat yang sudah menerima KBR, tidak diperkenankan untuk menerima lagi Bantuan Langsung Masyarakat Pengembangan Perhutanan Masyarakat Pedesaan Berbasis Konservasi (BLM-PPMPBK). Besaran dana dari kedua program ini sama yakni Rp. 50.000.000 per kelompok. Namun proses pencairan dana dilakukan tiga tahap masing-masing $40 \%$ tahap I, dan $30 \%$ tahap II dan Tahap III.

\section{Norma Adat}

Lembaga kultural masyarakat adat suku besar Arfak pemilik hak ulayat di Kabupaten Manokwari memiliki normanorma dan aturan-aturan yang disepakati secara turun temurun berupa sanksi dan larangan (social order/obedience). Namun dalam pelaksanaan program perhutanan sosial pembuatan KBR ini tidak mendapat sentuhan. Hal ini dikarenakan pembentukan kelompok tersebut tidak mengacu pada regulasi pemerintah yang mengatur tentang pedoman penyelenggaran kebun bibit rakyat yakni PERMENHUT No: P.12/Menhut-II/ 2013 dimana dalam Bab I Pendahuluan poin C. Pengertian pasal 3 menyebutkan "desa atau yang disebut dengan nama lain adalah kesatuan masyarakat hukum adat yang memiliki batas-batas wilayah yang berwenang untuk mengatur dan mengurus kepentingan masyarakat setempat, berdasarkan asal usul dan adat istiadat setempat yang diakui dan dihormati dalam sistem pemerintahan Negara Kesatuan Republik Indonesia".

Tidak dilibatkannya masyarakat adat juga berkaitan dengan tuntutan ganti rugi hak ulayat yang nilainya jauh lebih besar dari nilai proyek KBR. Sehingga pengurus biasanya menggunakan lokasi pembibitan pada lahan/pekarangan milik mereka sendiri. Masalah klasik dalam pengelolaan program PS pembuatan KBR ini sejak digulirkan oleh pemerintah pusat adalah akses informasi oleh masyarakat dalam pembentukn kelompok KBR dikarenakan tidak tranparansi dari pemerintah kepada masyarakat sehingga program KBR ini dianggap sebagai proyek yang habis kegiatan pembuatan kebun bibit masyarakat tidak melanjutkan secara swadaya. Dengan demikian aspek keberlanjutan (sustainability) tidak dapat dilaksanakan, dan program tersebut menjadi mubazir. Program PS/KBR ini tidak hanya diukur dari keberhasilan tanaman di persemaian namun sampai pada kegiatan penanaman di lokasi yag telah direncanakan. Bibit tanaman yang mati disebabkan lamanya waktu untuk penanaman selain faktor cuaca juga dikarenakan pencairan dana untuk penanaman belum juga ada pencairan sampai pada pertengahan tahun 2016 .

\section{Aturan Main dan Kebijakan Formal dan Norma Adat}

Aturan tertulis yang dibuat dan ditandatangani bersama antara Pejabat Pembuat Komitmen (PPK) Dinas Kehutanan Kabupaten Manokwari dan 
ketua kelompok pengelola kebun bibit rakyat KBR ini berupa SPKS (Surat Perjanjian Kerja Sama) antara pejabat pembuat komitmen dari Dinas kehutanan Kabupaten Manokwari dan ketua kelompok masyarakat pengelola kebun bibit rakyat tahun 2015. Aturan lisan/tidak tertulis dari masing-masing lembaga masyarakat pengelola program perhutanan sosial ini tidak ada. Kelembagaan masyarakat pengelola program PS pembuatan kebun bibit rakyat ini dari awal dibentuk sampai dengan saat pengambilan data penelitian ketiga kelompok/lembaga ini tidak mempunyai AD \& RT (Anggaran Dasar \& Anggaran Rumah Tangga). Sehingga merupakan suatu kelemahan dalam pengorganisasian kelembagaan dalam masyarakat guna mencapai tujuan yang ingin dicapai. $\mathrm{AD} \& \mathrm{RT}$ memuat hak dan kewajiban masing-masing anggota setiap orang dalam kelembagaan juga tidak ada.

\section{Fungsi Kelembagaan Masyarakat Dalam Program PS/KBR}

Kelompok kebun bibit rakyat Ofoncu Efeina dibentuk berdasarkan SK Kepala
Distrik Manokwari Barat Nomor: 522.4/SK.KBR/MKW-BRT/2015.

Berkedudukan di Kelurahan Amban. Kelompok KBR Ofoncu Efeina ini bersifat sosial ekonomi di bidang kehutanan, perkebunan, pertanian, perikanan dan peternakan. SK Kepala Distrik Manokwari Selatan No: 525/19/SK.KBR/MKW/2015 tentang Pembentukan Kelompok Kebun Bibit Rakyat Udopi Kampung Masepi Distrik Manokwari Selatan memutuskan dan menetapkan kelompok KBR ini bersifat sosial ekonomi di bidang kehutanan, perkebunan, pertanian, perikanan dan peternakan begitu pula dengan pembentukan kelompok KBR Sarina yang berkedudukan hukum di Distrik Manokwari Barat, Kelurahan Manokwari timur ditetapkan berdasarkan SK Kepala Distrik Manokwari Barat No: 522.5/SK.KBR/MKW/2015. bersifat sosial ekonomi di bidang kehutanan, perkebunan, pertanian, perikanan dan peternakan.

Tabel 2. Perkembangan kegiatan kebun bibit rakyat Kabupaten Manokwari tahun anggaran

\begin{tabular}{|l|l|c|l|l|l|}
\hline \multirow{2}{*}{ No. } & Nama KBR/Ketua & \multirow{2}{*}{$\begin{array}{c}\text { Lokasi } \\
\text { Kelompok }\end{array}$} & \multicolumn{3}{|c|}{ Perkembangan Bibit } \\
\cline { 4 - 6 } & & (Distrik \& Kampung) & \multicolumn{1}{|c|}{ Jenis } & \multicolumn{1}{c|}{ Target } & Realisasi \\
\hline 1. & KBR OFONCU EFEINA/ & Manokwari Barat & Mahoni & 5.000 & 5.000 \\
& Terianus Mandacan & (Manggoapi) & Merbau & 20.000 & 18.543 \\
& & & Total & $\mathbf{2 5 . 0 0 0}$ & $\mathbf{2 3 . 5 4 3}$ \\
\hline 2. & KBR SARINA/ & Manokwari Timur & Pinang & 10.000 & 9.213 \\
& Bobby Redjauw & (Sarina) & Nyatoh & 15.000 & 13.713 \\
& & & Total & $\mathbf{2 5 . 0 0 0}$ & $\mathbf{2 2 . 9 2 6}$ \\
\hline 3. & KBR UDOPI/ & Manokwari Selatan & Matoa & 5.000 & 3.442 \\
& Martinus Mandacan & (Masepi) & Nyatoh & 5.000 & 4.115 \\
& & & Merbau & 15.000 & 15.000 \\
& & & Total & $\mathbf{2 5 . 0 0 0}$ & $\mathbf{2 2 . 5 5 7}$ \\
\hline
\end{tabular}

Sumber : Dinhut Kab. Manokwari 2016. 
Ketiga kelembagaan masyarakat ini belum berjalan sesuai fungsinya dilihat dari pelaksanaan program kegiataan yang dilaksanakan hanya kegiatan perhutanan sosial pembuatan bibit tanaman guna penanaman hutan rakyat yang dilaksanakan sedangkan programprogram perhutanan sosial lainya seperti agroforestry tidak dilaksanakan.

Bantuan Langsung Masyarakat Program Perhutanan Masyarakat Berbasis Konservasi (BLM-PPMBK) yaitu pengembangan perhutanan masyarakat berbasis konservasi dimana Kabupaten Manokwari terdapat 17 kelompok masyarakat penerima program BLMPPMBK. Tahun 2014 terdapat 4 kelompok dan tahun 2015 terdapat 13 kelompok masyarakat penerima program. Kabupaten Manokwari mendapat alokasi BLM- PPMBK yang dikelola oleh lembaga 'Rumah Aspirasi' sedangkan PPK Dinas Kehutanan Kabupaten Manokwari tidak memiliki informasi bantuan sosial BLM-PPMBK. hal ini yang kemudian dapat menimbulkan konflik karena adanya kepentingan yang mempengaruhi arena aksi dalam pelaksanaan program pemberdayaan masyarakat PS di Kabupaten Manokwari.

\section{Analisis SWOT}

\section{Kekuatan (Strenght)}

Kelembagaan masyarakat program PS KBR memiliki struktur keanggotaan yang terdiri dari 15 orang yang diketuai oleh satu orang dan membawahi 14 orang anggota dengan posisi tim perencana tiga orang, tim pelaksana enam orang anggota, tim pengawas tiga orang, satu orang sekretaris dan satu orang bendahara. Aturan main/kebijakan formal dalam kelembagaan merupakan faktor kekuatan dalam pelaksanaan program KBR ini karena memuat hak dan kewajiban serta sanksi antar aktor pemerintah dan masyarakat pengelola program perhutanan sosial/ KBR ini berupa Surat Perjanjian Kerjasama/ SPKS. Keberhasilan pembuatan bibit tanaman pada ketiga kelompok mencapai rata-rata (92, 03\%) dan hal ini menunjukan keberhasilan yang perlu dipertahankan oleh masing-masing kelompok. Pemilik hak ulayat dilibatkan dalam keanggotan kelompok dan berperan sebagai ketua kelompok. Fungsi kelembagaan sudah berjalan sesuai fungsinya dibidang sosial ekonomi kehutanan dengan terlaksananya pembangunan KBR. Tingkat pendidikan keanggotan didominasi oleh anggota yang berlatar belakang pendidikan SLTA dengan jumlah 30 orang $(65,27 \%)$ diikuti perguruan tinggi 14 orang $(30,43 \%)$ sisanya SD satu orang $(2,17 \%)$ dan SMP satu orang $(2,17)$.

\section{Kelemahan (Weakness)}

Pencairan dana guna pelaksanaan kegiatan pembuatan KBR mengalami keterlambatan sehingga berdampak pada proses/pelaksanaan kegiatannya. Kurangnya pendampingan dari PL-KBR (pendamping lapangan KBR) sekali dalam sebulan melakukan pendampingan dengan alasan tidak adanya biaya operasional dalam melakukan pendampingan. RUKK terlambat dari jadwal yang ditetapkan yang seharusnya diusulkan pada bulan april tahun 2015 mengalami keterlambatan pengusulan sampai dengan bulan juni 2015 dan hal yang sama terjadi pada saat pembuatan perjanjian kerja/SPKS. Tidak adanya atribut komunitas dalam kelompok/kelembagaan masayarakat KBR yang mengelola kegiatan PS pembuatan kebun bibit ini. Kebijakan informal pada ketiga kelembgaan 
masyarakat pengelola KBR ini tidak ada berupa aturan main/AD \& ART. Luasan lokasi yang direncanakan guna penanaman/pembagunan HR berkisar antara 40 hektar sampai dengan 100 hektar. Hal ini merupakan faktor kelemahan dengan jumlah anggota tiap kelompok/ kelembagaan yang terdiri dari hanya 15 orang. Kelompok masyarakat/kelembagaan ini tidak mempunyai AD \& ART yang merupakan aturan main dalam kelompok ini yang memuat hak dan kewajiban anggota serta sanksi dan larangan (social order/kepatuhan). Keanggotaan dalam kelompok KBR dinilai sangat minim dengan jumlah yang hanya 15 orang sedangkan luasan areal yang direncanakan untuk ditanami berkisar dari 40 ha sampai dengan 100 ha. Perekrutan anggota kelompok tidak mengacu pada pedoman penyelenggaraan KBR/Peraturan Menteri Kehutanan No. P.12/ Menhut-II/ 2013. Ketiga kelembagaan ini merekrut anggota yang diluar domisili Kabupaten Manokwari yang dibuktikan dengan identitas anggota berupa identitas KTP.

\section{Peluang (Opportunity)}

Adanya dukungan dari pemerintah dengan program konvergensi bidang pertanian, perikanan, perkebunan dan peternakan, sehingga kelembagaan ini dapat melihat peluang yang ada guna kesejahteraan anggota dan pengembangan kedepan. Program penanaman bibit gaharu oleh Dinas kehutanan Provinsi Papua Barat merupakan program PS yang diselenggarakan oleh Dinas Kehutanan Provinsi Papua Barat berupa kegiatan budidaya gaharu. Kementerian Kehutanan dengan kegiatan aneka usaha perhutanan berbasis konservasi dalam bentuk BLM dan bantuan sosial kegiatan aneka usaha perhutanan berbasis konservasi yang diharapkan dapat meningkatkan pertumbuhan ekonomi dan kesejahteraan masyarakat desa di dalam dan sekitar kawasan hutan. Kegiatan ini terus dilanjutkan setiap tahunnya yang telah dimulai dari tahun 2013 sampai dengan tahun 2015. Keterlibatan masyarakat adat dalam kelembagaan merupakan peluang yang harus dilihat karena mereka pemilik lahan sehingga kedepan perekrutan anggota kelompok dari masyarakat adat lebih diutamakan. Banyaknya lulusan perguruan tinggi yang belum mendapat pekerjaan sehingga mereka dapat dilibatkan dalam keanggotaan kelompok dan mereka memberi sumbangan ilmu pengetahuan guna pengembangan kelembagaan masyarakat ini.

\section{Tantangan (Threat)}

Perubahan kebijakan nasioanal yang berdampak pada kelembagaan ini adalah dibuatnya regulasi baru mengenai pedoman KBR yang terus diperbaharui. Keadaan iklim yang terus berubah-ubah sehingga banyak bibit yang mati di persemaian. Tantangan lainya pembangunan perumahan pada lokasi yang telah ditanami di jalan baru (sowi gunung) sehingga tanaman hilang.

\section{Strategi Pengembangan Kelembagaan Masyarakat Dalam PS Dibangun Berdasarkan Analisis SWOT}

Berdasarkan data kualitatif yang didapat kemudian dikuantitatifkan dalam analisis SWOT (Pearce \& Robinson 1988) melalui tiga tahapan:

1. Melakukan perhitungan skor (a) dan bobot tiap poin faktor (b) serta jumlah total perkalian skor dan bobot $(\mathrm{c}=\mathrm{a} \times \mathrm{b})$ pada setiap faktor kekuatan dan kelemahan serta peluang dan tantangan. Menghitung 
skor dan poin faktor dilakukan secara bebas dan piihan rentang besaran skor sangat menentukan akurasi penilaian. Skor yang lazim digunakan 1 sampai 10 dengan asumsi nilai satu skor paling rendah dan nilai sepuluh skor paling tinggi.

2. Melakukan pengurangan jumlah total faktor kekuatan $(\mathrm{S})=414$ dengan kelemahan $(\mathrm{W})=426$ diperoleh $(-12)$ menjadi nilai/titik pada sumbu $X$. Pengurangan jumlah total peluang $(\mathrm{O})=$ 244 dengan tantangan (T) 205 diperoleh (39) menjadi nilai/titik pada sumbu Y

3. Mencari posisi organisasi yang ditunjukkan oleh titik $(\mathrm{X}=-12)$ dan $(\mathrm{Y}=$

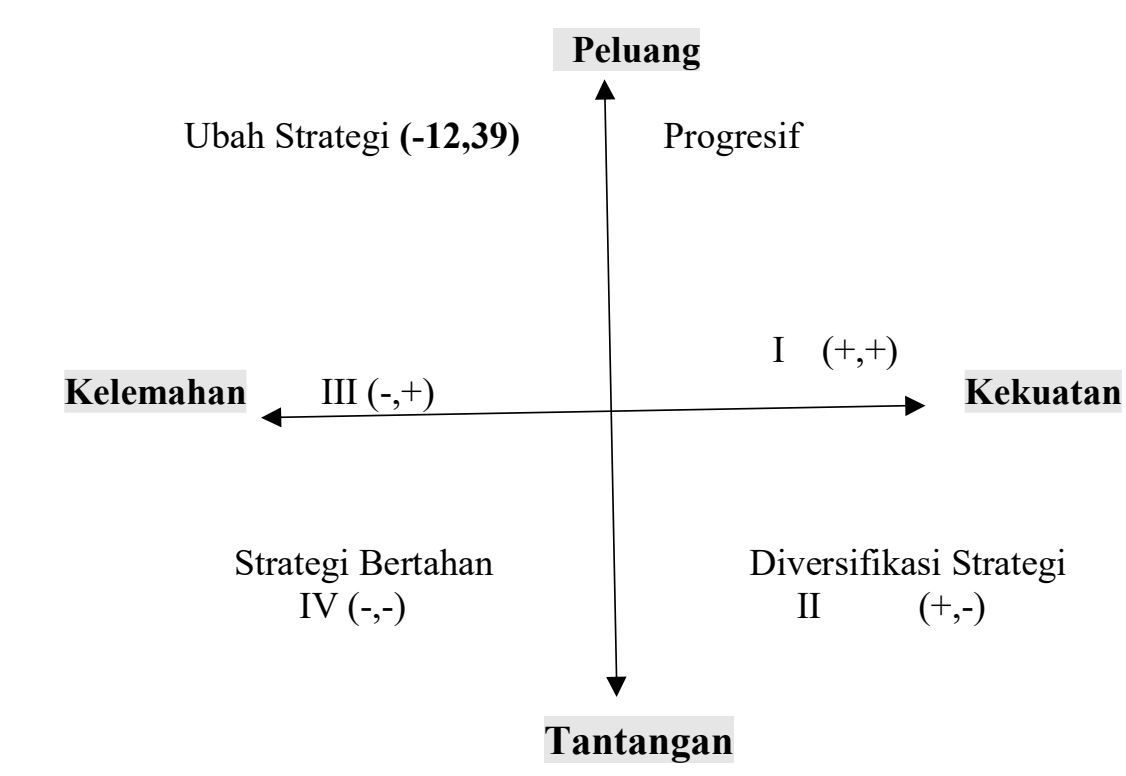

Gambar 3. Diagram analisis SWOT
39) maka pada kuadran SWOT posisi ketiga lembaga ini berada pada kuadaran III $(-12,39)$. Posisi ketiga kelembagan masyarakat yang melaksanakan program PS pembuatan bibit tanaman/KBR di Kabupaten Manokwari pada tahun 2015 berada pada posisi/kuadran III (negatif, positif) ini dikarenakan hasil dari selisih total kekuatan dikurangi total kelemahan hasilnya negatif (-12) yang merupakan faktor internal dan hasil total peluang dikurangi tantangan hasil positif (39) adalah faktor ekternal.

\begin{abstract}
Evaluasi kelembagaan masyarakat yang melaksanakan program PS pembuatan kebun bibit rakyat di Kabupaten Manokwari dinilai sangat lemah dan mengahadapi tantangan besar sehingga kelembagan ini dikembangkan dengan cara merubah strategi dengan cara lebih intensif membangun komunikasi dengan pemerintah dalam hal ini Dinas Kehutanan Kabupaten
\end{abstract}

$\begin{aligned} & \text { Manokwari, BPDAS Remu-Ransiki } \\ & \text { maupun pemerintah Kabupaten }\end{aligned}$
Manokwari.
Faktor-faktor yang melemahkan
seperti terlambatnya pencairan dana,
penyusunan rencana usulan kegiatan
kelompok/RUKK tidak sesuai dengan
waktu yang dijadwalkan, kurangnya
pendampingan dari penyuluh lapangan
KBR, minimnya jumlah anggota dalam


pelaksanaan kegiatan, tidak adanya aturan main dalam kelembagaan (ADART) dan terlibatnya anggota diluar domisili serta tidak adanya atribut komunitas dalam kelompok atau kelembagaan KBR.

Faktor tingkat pendidikan anggota dalam kelembagan ini didominasi oleh mereka yang berpendidikan SLTA dengan jumlah 30 orang $(65,27 \%)$. Namun ketiga kelembagaan dianggap masih lemah karena mereka tidak berkontribusi langsung dalam pelaksanaan kegiatan. Posisi ini menandakan sebuah organisasi yang lemah namun sangat berpeluang untuk dikembangkan dalam pelaksanaan program perhutanan sosial dengan cara merubah strategi, artinya organisasi kelembagaan masyarakat pengelola kebun bibit rakyat ini disarankan untuk mengubah strategi sebelumnya. Sebab, strategi yang lama dikhawatirkan sulit untuk dapat menangkap peluang yang ada sekaligus memperbaiki kinerja organisasi (Pearce and Robinson 1988).

Faktor dari luar berada pada posisi/angka positif 39 pada kuadran III diagram SWOT yang mana situasi ini menandakan bahwa peluang dari luar sangat besar jika kelembagaan masyarakat mampu merebut peluang seperti adanya program konvergensi dari pemerintah, program penanaman bibit gaharu dari Dinas Kehutanan Provinsi Papua Barat, Bantuan Sosial BLMPPMBK dari Kementrian Lingkungan Hidup dan Kehutanan. Kondisi ini juga diperlihatkan dalam pengembangan sektor pemanfaat kayu oleh masyarakat local pemilih ulayan di Kabupaten Biak yang dilaporkan oleh Maran dkk (2017). Keterlibatan masyarakat adat dinilai sangat kurang dalam pengelolaan program PS/KBR dan ini merupakan kelemahan kelembagaan setelah dievaluasi sehingga kedepan lembaga ini harus merubah strategi dengan cara merekrut mereka yang berdomisili di kampung setempat dimana pelaksaan program ini berlangsung. Peluang lainnya yaitu merekrut lulusan perguruan tinggi yang belum mendapat pekerjaan menjadi anggota kelompok/kelembagaan ini.

\section{DAFTAR PUSTAKA}

Aji GB, Yuliyanti R, Suryanto J, Ekaputri AD, Saptono T dan Muis H. 2015. Sumbangan hutan kemasyarakatan dan hutan desa terhadap pendapatan dan pengurangan kemiskinan. Kemitraan bagi Pembaruan Tata Pemeritahan di Indonesia. Lembaga Ilmu Pengetahuan Indonesia.

Elisabeth K. 2017. Pemberdayaan masyarakat melalui kebijakan hutan kemasyarakatan untuk menciptakan kesejahteraaan (Studi kasus kelompok HKm Karya Bersama di Kampung Marga Jaya Kecamatan Selagai Lingga Kabupaten Lampung Tengah). Skripsi Ilmu Sosial dan Ilmu Politik, Universitas Lampung.

Firdaus AY. 2018. Panduan praktis penerapan kebijakan perhutanan sosial: Kerangka percepatan reformasi tenurial hutan. Bogor, Indonesia: CIFOR.

Kartodihardjo H. 2006. Masalah kelembagaan dan arah kebijakan rehabilitasi hutan dan lahan. Jurnal Analisis Kebijakan Kehutanan, Vol 3 (2): 29-41.

Maran JA, Marwa J dan Sinery AS. 2017. Skema pembagian manfaat dan stakeholders terhadap pengelolaan hutan damar (Agathis labilardieri Warb.) Distrik Biak Timur Kabupaten 
Biak Numfor. Jurnal Kehutanan Papuasia, Vol 3 (1): 1-13.

Ostrom E. 2008. Institutions and the environment. The economic analysis institiutions. IEA Economic Affairs September 2008.

https://onlinelibrary.wiley.com/doi/pdf /10.1111/j.1468-0270.2008.00840.x.
Pearce JA and Robinson RB. 1988. In: Strategic management: Strategy formulation and implementation. Oxford Publication, UK, p. 450.

Puspitojati T, Mile MY, Fauziah E dan Darusman D. 2014. Hutan rakyat: Sumbangsih masyarakat pedesaan untuk hutan tanaman. Penerbit PT. Kanisius, Yogyakarta. 